\title{
IZIN POLIGAMI DARI ISTRI DI PENGADILAN DALAM PERSPEKTIF MASHLAHAH MURSALAH
}

\author{
Zulfan Efendi \\ STAIN Sultan Abdurrahman Kepulauan Riau \\ zefendi801@gmail.com
}

\begin{abstract}
Abstrak
Artikel ini hendak melihat aturan hukum perihal perlunya izin dari istri bagi pria yang akan berpoligami dari perspektif mashlahah mursalah. Satu di antara persyaratan dalam acara persidangan ialah perlunya pengadilan mendapatkan keterangan izin dari istri serta perlu memeriksa dan klarifikasi dari istri yang memberikan izin. Dalam penelitian ini disimpulkan bahwa izin dari istri yang disampaikan di hadapan persidangan merupakan kebutuhan pokok (mashlahah hajiyah) untuk melindungi kebutuhan mutlak (mashlahah daruriyah) yang berupa kebahagiaan dalam rumah tangga. Dari penelitian terdahulu dengan fokus pada dampaknya menyatakan, sebagian besar istri tidak dengan tulus memberikan izin poligami. Maka dari itu, pengadilan wajib menghadirkan istri untuk mendapatkan keterangan langsung atas izin poligami yang diberikan kepada suami.
\end{abstract}

Abstract: This article would like to see the rule of law related the need of consent from a wife for her husband who will do polygamy from the perspective of mashlaha mursalah. One of the requirements in a court session is the need for the court to obtain a consent statement from the wife and need to check and confirm the wife's consent. In this study, it was concluded that the consent of the wife conveyed before the trial is a fundamental need (mashlahah hajiyah) to protect the absolute need (mashlahah daruriyah) in the form of happiness in the household. Based on related studies focusing on the impact, most wives did not sincerely give their consent for polygamy. Therefore, the court must invite the wife to obtain direct information on the consent of polygamy given to her husband.

Keyword: Perkawinan, Poligami, Istri, Pengadilan Agama

\section{Pendahuluan}

Poligami menjadi pembahasan yang terus berkembang seiring dengan pemahaman terhadap ajaran dokmatis agama dan aturan perundang-undangan yang berlaku di suatu negara. Di Indonesia, Undang-Undang Nomor 74 Tahun 1974 tentang Perkawinan secara menganut asas perkawinan monogami. ${ }^{1}$ Namun, karena dalam ajaran agama Islam terdapat kebolehan untuk melakukan poligami, undang-undang tersebut memberikan pengecualian. Dalam perkembangan aturan perundang-undangan, ketentuan lebih lanjut

1 UU No. 1 tahun 1974 pasal 3 ayat 1 yang menyatakan bahwa "Pada asasnya seorang pria hanya boleh memiliki seorang isteri. Seorang wanita hanya boleh memiliki seorang suami”. perihal poligami juga diatur dalam Instruksi Presiden Nomor 1 Tahun 1991 tentang Kompilasi Hukum Islam (KHI).

Realitas normatif di atas juga berbanding lurus dengan realitas sosial. Praktik poligami juga masih banyak dilakukan masyarakat Indonesia dengan berbagai alasannya. Dalam realitas sosial juga dikenal dengan istilah nikah siri, yakni pernikahan yang dilakukan secara agama dan tidak didaftarkan pada pencatatan nikah di Kantor Urusan Agama (KUA). ${ }^{2}$ Bahkan nikah siri ini banyak terjadi pada pernikahan poligami karena tidak

2 Zainuddin dan Afwan Zainuddin, Kepastian Hukum Perkawinan Siri dan Permasalahannya Ditinjau dari Undang-Undang Nomor 1 Tabun 1974 (Yogyakarta: Deepublihs, 2017), h. 51 
mendapatkan izin dari istrinya. Dalam perspektif fikih klasik, tidak ada syarat dan ketentuan adanya izin dari istri untuk suami yang akan berpoligami, namun dalam perkembangan kontemporer banyak ulama mewacanakan perlunya adanya izin dari istri sebagai satu di antara persyaratan poligami.

Sumber hukum yang menjadi sandaran utama dalam praktik poligami ialah nash Alquran surat An-Nisa' ayat 3. Ayat tersebut menjadi justifikasi bagi diperbolehkannya seorang lelaki untuk menikahi perempuan lebih dari satu dengan persyaratan yang juga termaktub di dalamnya. Adanya pembatasan hanya empat perempuan saya yang dibolehkan menjadi isteri tidak lepas dari faktor historisnya sehingga turunlah ayat tersebut sebagai bentuk pembatasan jumlah istri beserta persyaratan yang harus dipenuhi oleh seorang pria yang hendak melakukan poligami. ${ }^{3}$ Keadilan suami, dalam ayat tersebut ditak tidak terdapat persyaratan lain bagi perkawinan poligami. Adil pun kemudian menjadi pembahasan yang cukup panjang dikalangan ulama, baik dari sisi lahir maupun batil.

Para ulama memiliki persyaratan berbeda selain dalam memaknai kata adil dalam ayat tersebut. Khairudn Nasution mengemukakan pendapat al-Maraghy, yang memberikan empat alasan diperbolehkannya poligami, yakni istri mandul, gairah seks suami tinggi yang tidak mampu dilayani istri, kemampuan finansial pria untuk menafkasi keluarga, jumlah perempuan melebihi jumlah laki-laki, yang bisa jadi dikarenakan terjadinya perang. Akibat lain

${ }^{3}$ Menuurut para ahli sejarah, model perkawinan poligami sudah berlangsung sejak lama dan diakui oleh banyak peradaban bangsa-bangsa dunia. Candra Sabtia Irawan, Perkawinan dalam Islam: Monogami atau Poligami?, (Yogyakarta: An Naba', 2007), h. 20. Lihat juga Makrum, Poligami dalam Perspektif Al-Qur'an, MAGHZA: Jurnal Ilmu Al-Qur'an dan Tafsir, 2016, 1.2. h. 35-50. yang terjadi akibat perang adalah banyaknya anak yatim dan janda yang perlu dilindungi. ${ }^{4}$

Argumen yang serupa juga disampaikan oleh Amir Syarifuddin. Menurut dia, alasan poligami dalam Islam di antaranya faktor seksualitas pria yang tidak terlayani oleh istri, tidak mempunyai ketuturan, istri menderita penyakit yang menyebabkannya tidak bisa melayani suaminya, dan karena jumlah pria lebih banyak dari perempuan. ${ }^{5}$ Sedangkan menurut Muhammad Shahrur, syarat yang harus terpenuhi, yaitu istri kedua, ketiga, dan keempat adalah para janda yang memiliki anak yatim dan harus terdapat rasa khawatir tidak dapat berbuat adil kepada anak-anak yatim. ${ }^{6}$

Selain diskursus perihal alasan-alasan tersebut, praktik poligami tentu menimbulkan dampak bagi rencana rumah tangga yang bahagia. Bagaimana tidak, dalam satu pasangan saja masih akan terjadi selisih pendapat atau cekcok, apalagi jika seorang pria memiliki lebih dari satu pasangan. Sedangkan esensi pernikahan ialah kebahagian masing-masing pasangan. Oleh sebab itu, kondisi psikologis istri juga patut menjadi perhatian penting dalam praktik poligami yang dilakukan oleh suami. Dalam penelitian Sri W. Rahmawati menyebutkan, faktor pengambilan keputusan yang dilakukan oleh istri untuk menerima dipoligami seringkali tidak berdasarkan pada keputusan sepenuh hati. Melainkan lebih banyak faktor ekternal yang memperngaru istri

${ }^{4}$ Khoirudin Nasution, Riba \& Poligami: Sebuah Studi atas Pemikiran Mubammad Abduh, (Yogyakarta: Pustaka Pelajar, 1996), h. 84.

5 Amir Syarifuddin, Hukum Perkawinan Islam di Indonesia: Antara Fiqh Munakahat dan Undang-Undang Perkawinan, (Jakarta: Kencana, 2007), h. 25

${ }^{6}$ Muhammad Shahrur, "Nabw Usul Jadidah Li alFiqh al-Islami" terj., Sahiron Syamsuddin dan Burhanuddin, Metodologi Fiqh Islam Kontemporer, (Yogyakarta: eLSAQ Press, 2004), h. 428 
dalam mengambil keputusan menerima berpoligami. ${ }^{7}$

Dari latar belakang di atas, terlihat jelas bahwa praktik poligami itu dampak psikologis terhadap perempuan meskipun praktik ini diperbolehkan menurut aturan normatif agama maupun undang-undang yang berlaku di Indonesia. Dalam peraturan di Indonesia, seorang suami yang hendak menikahi lagi, yakni pernikahan poligami, maka salah satu syaratnya ialah mendapatkan izin dari istri dan ketetapan dari Pengadilan Agama (PA). Secara lebih detail, aturan persyaratan dan mekanisme untuk berpoligami bagi pria akan dibahas lebih lanjut.

Adanya diskursus dalam poligami ini menarik untuk untuk dikaji lebih lanjut, khususnya perihal izin dari istri bagi suami yang hendak berpoligami dari perspektif hukum Islam sebab ketentuan fikih pada dasarnya tidak mensyaratkan adanya izin dari istri dan apalagi penetapan dari pengadilan maupun pejabat berwenang. Sebab itu, artikel ini hanya memfokuskan pada bahasan tentang izin dari istri di pengadilan dari perspektif hukum Islam.

\section{Mashlahah Mursalah dalam Kajian Hukum Islam}

Dalam kajian hukum Islam, ada banyak metode yang berkembang untuk menemukan hukum, satu di antaranya ialah mashlahah mursalah. Banyak ahli yang menilai bahwa mashalahah mursalah merupakan metode ijtihad yang paling tua namun baru mendapatkan tempat kembali pada era abad pertengahan. Istilah mashlahah mursalah dikenalkan pertama kali oleh Imam Malik. Namun, kajian ini berkembang pesat setelah

${ }^{7}$ Sri W. Rahmawati, Pengambilan Keputusan Seorang Istri dalam Pernikahan Poligami, Jurnal Psikologi Ulayat: Indonesian Journal of Indigenous Psychology, 1(2) (2013), 163-176.
Imam Haramain, Abu Hamid al-Ghazali, dan Asy-Syatibi mengulas dan menjiadikannya sebagai pedoman telaah hukum. Dari ketiga tokoh inilah kemudian terjadi pekembangan langkap operasional mashlahah mursalah ketika dijadikan sebagai metode ijtihad. ${ }^{8}$ Metode ini ditengarai mampu menjawab persoalan dari perspektif hukum Islam yang tidak ada dalil dalam nash.

Menurut Imam Al-Ghazali, sebagaimana dikutip oleh Wahyu Abdul Jafar, mashlahah itu berintikan menarik manfa at dan menolak mudharat, baik yang bersifat urusan keagamaan maupun keduniaan. Maksud dari pendevinisan itu ialah kesesuaian untuk memelihara substansi dari tujuan hukum Islam. ${ }^{9}$ Dengan cara menarik manfaat dan menolak mudhorat inilah, maka sesuatu perkaran bisa terima oleh hukum Islam. Tolok ukur kemashlahatan itu ialah mengacu pada tujuan syariat (maqashid syariah) yang terumuskan dalam tiga hal, yakni yang bersifat mutlak (dharuriyah), kebutuhan pokok (hajiyah) dan kebutuhan tambahan (tahsiniyah).

Dalam kajian ini, penulis menilai metode mashlahah mursalah mampu untuk menjadi pisau analisa dalam membedah pokok bahasan artikel. Metode ini dinilai mampu mengungkap nalar filosofis atas pokok bahasan tema sehingga memunculkan kesimpulkan yang lebih komprehensif dan bermanfaat dalam kajian akademis.

8 Ulasan lebih lengkap lihat Rusfi, Muhammad, Validitas Maslahah Mursalah Sebagai Sumber Hukum, Al'Adalah, 2017, 2 12.1: 63-74. http://ejournal.radenintan.ac.id/index.php/adalah/artic le/view/175/415 dan Wahyu Abdul Jafar, Kerangka Istinbath Maslabah Mursalah Sebagai Alternatif Problem Solving Dalam Hukum Islam, ISTINBATH: Jurnal Hukum, 2016, 13.1: 89-108. http://ejournal.metrouniv.ac.id/index.php/istinbath/article/vie w/544 (diakses 18 Agustus 2018). Sumber rujukan pada bagian ini juga mengacu pada dua artikel tersebut.

${ }_{9}$ Lihat Wahyu Jafar, Kerangka Istinbath Maslahah

Mursalah, h. 102 


\section{Aturan Poligami di Indonesia}

Awalnya, hukum tentang perkawinan di Indonesia mengacu pada Kitab Undangundang Hukum Perdata (KUHPer). Aturan umum yang ada di dalam dinilai terlalu makro dan dinilai belum mencerminkan atas hukum yang berlaku pada masyarakat Indonesia, sehingga lahirlah Undang-Undang Nomor 1 Tahun 1974 tentang Perkawinan. Sedangkan aturan pelaksananya berupa Peraturan Pemerintah (PP) Nomor 9 Tahun 1975. Karena kebutuhan hukum akan pernikahan yang sesuai dengan norma-norma ajaran Islam, maka pemerintah melahirkan Instruksi Presiden Nomor 1 Tahun 1991 tentang Kompilasi Hukum Islam.

Pada dasarnya, aturan hukum yang berlaku di Indonesia tentang pernikahan menganut asas monogami. Meski demikian, dalam aturan tersebut termuat juga aturan pengecualian yang membolehkan laki-laki melakukan poligami sebagaimana disebutkan dalam pasal 3 ayat (2) UU Pernikahan, "Pengadilan, dapat membeii izin kepada seorang suami untuk beristeri lebih dan seorang apabila dikehendaki oleh pihak-pihak yang bersangkutan." Menurut penjelasan umum angka 4 c UU No. 1 Tahun 1974, poligami hanya diperuntukkan bagi mereka yang hukum dan agamanya mengizinkan seorang suami beristeri lebih dari seorang. Hal ini terlihat jelas bahwa kebolehan poligami itu hanyalah bila ketentuan normatif dari agama membolehkan.

Keterangan labih lanjut perihal perkawinan poligami ini disebutkan pada pasal 4 dan pasal 5. Petikan langkap dari bunyi pasal tersebut ialah sebagai berikut:

\section{Pasal 4}

1. Dalam hal seorang suami akan beristeri lebih dari seorang.
Sebagaimana disebut dalam pasal 3 ayat (2), maka ia wajib untuk mengajukan pemohonan kepada Pengadilan di daerah tempat tinggalnya.

2. Pengadilan dimaksud dalam ayat (1) pasal ini, hanya memberikan izin kepada seorang suami yang akan beristeri lebih dari seorang apabila:

a. isteri tidak dapat menjalankan kewajibannya sebagai isteri;

b. isteri mendapar caeat badan atau penyakit yang tidak dapat disembuhkan;

c. isteri tidak dapat melahirkan keturunan.

\section{Pasal 5}

1. Untuk dapat mengajukan pemwhonan kepada Pengadilan. Sebagaimana ditnaksud dalam pasal 4 ayat 1 undang-undang ini. harus dipenuhi syarat-syarat sebagai berikut:

a. adanya persetujuan dari isteri/isteri-isteri;

b. adanya kepastian bahwa suami mampu menjamin keperluan keperluan hidup isteri-isteri dan anak-anak mereka;

c. adanya jaminan bahwa suami akan berlaku adil terhadap isteriisteri dan anak-anak mereka.

2. Persetujuan yang ditnaksud pada ayat 1 huruf a pasal ini tidak diperlukan bagi seorang suami apabila isteri/isteri-isterinya tidak mungkin dimintai persetujuarmya dan tidak dapat menjadi pihak dalam perjanjian, atau apabila tidak ada kabar dari isterinya selama sekurang-kurangnya 2 (dua) tahun atau karena sebab- 


\section{sebab lainnya yang perlu mendapat penilaian hakim.}

Mekanisme terkait dengan aturan poligami ini diatur dalam PP Nomor 1 Tahun 1975 sebagai aturan pelaksana UU Perkawinan. Tampaknya, aturan ini telah memberikan porsi penjelasan yang lebih khusus terkait poligami karena dibuat pada satu bab tersendiri yakni pada BAB VIII tentang Beristri Lebih dari Seorang. Bab ini memuat lima pasal sebagaimana yang akan dikutip secara lengkap di bawah ini.

\section{Pasal 40}

Apabila seorang suami bermaksud untuk beristeri lebih dari seorang maka ia wajib mengajukan permohonan secara tertulis kepada Pengadilan.

\section{Pasal 41}

Pengadilan kemudian memeriksa mengenai:

a. Ada atau tidaknya alasan yang memungkinkan seorang suami kawin lagi, ialah:

- bahwa isteri tidak dapat menjalankan kewajibannya sebagai isteri;

- bahwa isteri mendapat cacat badan atau penyakit yang tidak dapat disembuhkan;

- bahwa isteri tidak dapat melahirkan keturunan.

b. ada atau tidaknya persetujuan dari isteri, baik persetujuan lisan maupun tertulis, apabila persetujuan itu merupakan persetujuan lisan, persetujuan itu harus diucapkan di depan sidang pengadilan. c. ada atau tidak adanya kemampuan suami untuk menjamin keperluan hidup isteriisteri dan anak-anak, dengan memperlihatkan:

i. surat keterangan mengenai penghasilan suami yang ditanda-tangani oleh bendahara tempat bekerja; atau

ii. surat keterangan pajak penghasilan; atau

iii. surat keterangan lain yang dapat diterima oleh Pengadilan;

d. ada atau tidak adanya jaminan bahwa suami akan berlaku adil terhadap isteri-isteri dan anakanak mereka dengan pernyataan atau janji dari suami yang dibuat dalam bentuk yang ditetapkan untuk itu.

\section{Pasal 42}

1. Dalam melakukan pemeriksaan mengenai hal-hal pada Pasal 40 dan 41, Pengadilan harus memanggil dan mendengar isteriyang bersangkutan.

2. Pemeriksaan Pengadilan untuk itu dilakukan oleh Hakim selambat-lambatnya $30 \quad$ (tiga puluh) hari setelah diterimanya, surat permohonan beserta lampiran-lampirannya.

\section{Pasal 43}

Apabila Pengadilan berpendapat bahwa cukup alasan bagi pemohon untuk beristeri lebih dari seorang, maka Pengadilan memberikan putusannya yang berupa izin untuk beristeri lebih dari seorang.

Pasal 44 
Pegawai Pencatat dilarang untuk melakukan pencatatan perkawinan seorang suami yang akan beristeri lebih dari seorang sebelum adanya izin Pengadilan seperti yang dimaksud dalam Pasal 43.

Ketentuan poligami yang termuat dalam pasal-pasal di atas berlaku umum seluruh warga negara Indonesia. Sedangkan ada juga aturan khusus untuk umat Islam sebagaimana yang terangkum dalam KHI dan juga aturan bagi Pegawai Negeri Sipil (PNS) pria hendak menikah lebih dari satu istri sebagaimata termuat dalam PP Nomor 10 Tahun 1983 tentang Izin Perkawinan dan Perceraian Bagi Pegawai Negeri Sipil jo. PP Nomor 45 Tahun 1990 tentang Perubahan Atas Peraturan Pemerintah Nomor 10 Tahun 1983 Tentang Izin Perkawinan Dan Perceraian Bagi Pegawai Negeri Sipil.

Dalam KHI ketentuan tentang poligami juga menjadi bahasan dalam bab tersendiri, yakni pada Bab IX dengan memuat lima pasal. Berikut adalah petikan lengkap dari lim pasal tersebut.

\section{Pasal 55}

1. Beristeri lebih satu orang pada waktu bersamaan, terbatas hanya sampai empat isteri.

2. Syarat utama beristeri lebih dari seorang, suami harus mampu berlaku adil terhadap ister-isteri dan anak-anaknya.

3. Apabila syarat utama yang disebut pada ayat (2) tidak mungkin dipenuhi, suami dilarang beristeri dari seorang.

$$
\text { Pasal } 56
$$

1. Suami yang hendak beristeri lebih dari satu orang harus mendapat izin dari Pengadilan Agama.
2. Pengajuan permohonan Izin dimaksud pada ayat (1) dilakukan menurut pada tata cara sebagaimana diatur dalam Bab.VIII Peraturan Pemeritah No.9 Tahun 1975.

3. Perkawinan yang dilakukan dengan isteri kedua, ketiga atau keempat tanpa izin dari Pengadilan Agama, tidak mempunyai kekuatan hukum.

$$
\text { Pasal } 57
$$

Pengadilan Agama hanya memberikan izin kepada seorang suami yang akan beristeri lebih dari seorang apabila :

a. isteri tidak dapat menjalankan kewajiban sebagai isteri;

b. isteri mendapat cacat badan atau penyakit yang tidak dapat disembuhkan;

c. isteri tidak dapat melahirkan keturunan.

\section{Pasal 58}

1. Selain syarat utama yang disebut pada pasal 55 ayat (2) maka untuk memperoleh izin pengadilan Agama, harus pula dipenuhi syarat-syarat yang ditentukan pada pasal 5 UndangUndang No.1 Tahun 1974 yaitu :

a. adanya pesetujuan isteri;

b. adanya kepastian bahwa suami mampu menjamin keperluan hidup ister-isteri dan anakanak mereka.

2. Dengan tidak mengurangi ketentuan pasal 41 huruf $b$ Peraturan Pemerintah No. 9 Tahun 1975,

3. persetujuan isteri atau isteri-isteri dapat diberikan secara tertulis atau denganlisan, tetapi sekalipun 
telah ada persetujuan tertulis, persetujuan ini dipertegas dengan persetujuan lisan isteri pada sidang Pengadilan Agama.

4. Persetujuan dimaksud pada ayat (1) huruf a tidak diperlukan bagi seorang suami apabila isteri atau isteri-isterinya tidak mungkin dimintai persetujuannya dan tidak dapat menjadi pihak dalam perjanjian atau apabila tidak ada kabar dari isteri atau isteriisterinyasekurang-kurangnya 2 tahun atau karena sebab lain yang perlu mendapat penilaian Hakim. Pasal 59

Dalam hal istri tidak mau memberikan persetujuan, dan permohonan izin untuk beristeri lebih dari satu orang berdasarkan atas salh satu alasan yang diatur dalam pasal 55 ayat (2) dan 57, Pengadilan Agama dapat menetapkan tenyang pemberian izin setelah memeriksa dan mendengar isteri yang bersangkutan di persidangan Pengadilan Agama, dan terhadap penetapan ini isteri atau suami dapat mengajukan banding atau kasasi.

Dari petikan bunyai Bab IX tentang pernikahan lebih dari satu istri pada KHI di atas terlihat bahwa aturan ini menguatkan UU Perkawinan, sebagaimana yang terdapat pada pasal 56, pasal 58 dan pasal 59. Namun, karena tujuan KHI pada dasarnya untuk warga negara yang beragama Islam, maka KHI menjadi aturan tambahan yang bersifat khusus. Begitu juga aturan khusus yang berlaku bagi PNS yang hendak melakukan praktik poligami dengan syarat dan ketentuan-ketentuan tambahan seperti pada pasal 10 yang berbunyi sebagai berikut.

\section{Pasal 10}

1. Izin untuk beristri lebih dari seorang hanya dapat diberikan oleh Pejabat apabila memenuhi sekurang-kurangnya salah satu syarat alternatif dan ketiga syarat kumulatif sebagaimana dimaksud dalam ayat (2) dan ayat (3) Pasal ini;

2. Syarat alternatif sebagaimana dimaksud dalam ayat (1) ialah:

a. isteri tidak dapat menjalankan kewajibannya sebagai isteri;

b. isteri mendapat cacat badan atau penyakit yang tidak dapat disembuhkan; atau

c. isteri tidak dapat melahirkan keturunan.

3. Syarat kumulatif sebagaimana dimaksud dalam ayat (1) ialah:

a. ada persetujuan tertulis dari isteri;

b. Pegawai Negeri Sipil pria yang bersangkutan mempunyai penghasilan yang cukup untuk membiayai lebih dari seorang isteri dan anak anaknya yang dibuktikan dengan surat keterangan pajak penghasilan; dan

c. ada jaminan tertulis dari Pegawai Negeri Sipil yang bersangkutan bahwa ia akan berlaku adil terhadap isteri-isteri dan anak-anaknya.

4. Izin untuk beristeri lebih dari seorang tidak diberikan oleh Pejabat apabila:

a. bertentangan dengan ajaran/peraturan agama yang dianut Pegawai Negeri Sipil yang bersangkutan;

b. tidak memenuhi syarat alternatif sebagaimana dimaksud dalam ayat 
(2) dan ketiga syarat kumulatif dalam ayat (3);

c. bertentangan dengan peraturan perundang-undangan yang berlaku;

d. alasan yang dikemukakan bertentangan dengan akal sehat; dan/atau

e. ada kemungkinan mengganggu pelaksanaan tugas kedinasan.

Sebagaimana yang menjadi fokus pembahasan dalam artikel ini, izin dari istri itu termuat pada poin pertama dalam pasal $5 \mathrm{UU}$ Perkawinan. Artinya, setiap pernikahan yang dilakukan oleh seorang pria yang sedang beristri, haruslah mendapatkan izin dari istri ataupun istri-istrinya. Para pakar menilai bahwa persyaratan izin dari istri tersebut sebagai upaya memperjelas kerelaan dari istri yang sudah dinikahi. Menurut Ahmad Rafiq, aturan ketat untuk poligami untuk mencegah timbulnya berbagai akibat negatif dalam kehidupan rumah tangga, baik dari segi mental, psikologi sosial maupun ekonomi yang dapat merugikan seluruh anggota keluarga. ${ }^{10}$

Dalam mekanismenya, izin dari istri haruslah bisa berupa izin tertulis ataupun lisan sebagaimana dijelaskan PP Nomor 1 Tahun 1975. Dari beberapa observasi awal, banyak izin dari istri ini hanyalah berupa izin tertulis saja tanpa dimintai keterangan langsung di pengadilan. Hal ini karena ada bunyi ketentuan pada PP nomor 1 Tahun 1975 pasal 41 poin b, "ada atau tidaknya persetujuan dari isteri, baik persetujuan lisan maupun tertulis, apabila persetujuan itu merupakan persetujuan lisan, persetujuan itu harus diucapkan di depan sidang pengadilan.” Dengan hanya izin tertulis saja, maka tidak menutup kemungkinan surat pernyataan pemberian izin itupun ditulisankan dengan penuh keterpaksaan.

10 Ahmad Rofiq, Hukum Islam di Indonesia, (Jakarta: PT. Raja Grafindo Persada, 2000), h. 172
Menurut penelitian Sri W. Rahmawati, pada dasarnya, perempuan dalam kondisi normal sulit memberikan izin poligami pada suaminya. Namun, yang membuat para istri akhirnya luluh dan memberikan izin ialah karena faktor pengaruh dari lingkungan sekitar, baik dari keluarga maupun masyarakat umumnya. Menurut dia, proses pengambilan keputusan seorang istri justru karena tidak mempertimbangkan faktor internal dirinya sendiri. Terkadang, istri menerima dipoligami justru untuk menyelamatkan pernikahannya. ${ }^{11}$ Karena itulah perlunya pengadilan memeriksa izin dari seorang istri secara langsung dengan tidak hanya mengandalkan izin tertulis saja.

\section{Urgensi Izin Istri di Pengadilan dalam Perspektif Mahslahah Mursalah}

Sejatinya, aturan perundang-undangan menjadi hukum untuk mengatur kebaikan bagi seluruh subyek hukum. Dalam struktur hukum, aturan itu harus dijalankan menurut ketentuan formalnya agar sesuai dengan subtansinya sehingga terhindar dari perbuatan yang melanggar hukum itu sendiri. Karena itu, dalam setiap pengambilan keputusan hukum, semua pihak perlu memperhatian aturan formal agar tidak terjadi pelanggaran. Demikian juga yang berlaku pada hukum poligami.

Sebagaimana telah disebutkan di atas, ketentuan-ketentuan hukum poligami dalam UU No. 1 Tahun 1974, jo. PP No. 9 Tahun 1975 jo. Kompilasi Hukum Islam (KHI) adalah bersifat mengatur pelaksanaan kebolehan berpoligami menurut hukum Islam, dan bukan menutup kebolehannya. Atik Wirdani dalam penelitiannya menyimpulkan bahwa sebagain besar negara muslim pun mensyaratkan adanya izin dari istri dan

11 Sri W. Rahmawati, Pengambilan Keputusan Seorang Istri, h. 176 
ketetapan pengadilan dalam poligami. ${ }^{12} \mathrm{Hal}$ ini sebagai bagian dari ijtihad dalam upaya meminimalisir dampak dari praktik poligami. Sebab itulah, faktor material seja tidak cukup untuk menjadi landasan hakim dalam memberikan izin poligami, melainkan juga harus melihat dari sisi-sisi lain, sebagaimana yang diamanatkan dalam aturan perundangundang yang berlaku di Indonesia. Sebab, masalah poligami jelas yang menjadi kebijakan adalah para hakim di pengadilan agama.

Supaya tidak menimbulkan dampak bagi rumah tangga yang pertama, maka persyaratan mendapatkan izin dari istri atau istri-istri menjadi syarat supaya tidak ada penyalahgunaan, adanya keputusan pengadilan merupakan upaya ijtihad harus berdasarkan pada kemashlahatan. Apalagi, dalam pernikahan itu memuat maqashid al-syariah. Sedangkan terkait poligani, setiap hakim perlu mengambil kebijakan dari pertimbangan izin dari istri karena pada kenyataannya tidak sedikit suami yang sewenang-wenang melakukan poligami dengan menyalahgunakan kebolehan poligami.

Perlunya izin isteri didasarkan pada prinsip keseimbangan hak dan kedudukan suami isteri, dan didasarkan pada prinsip bahwa hal tersebut memang dikehendaki oleh pihak-pihak (suami-isteri) yang bersangkutan. Dengan demikian prinsip tersebut dimaksudkan untuk menghindarkan timbulnya penyalahgunaan dan kesewenang-wenangan satu terhadap yang lain. Dalam hal ini, dari perspektif mashlahah, maka di dalamnya terkandung mashlabah al-daruriyah, yakni harus dijadikan sebagai perkara utama dalam memeriksa izin tersebut.

Izin dari istri masuk dalam kategori dharuriyah karena itu termasuk bagian penting

12 Atik Wartini, Poligami: Dari Figh Hingga Perundang-Undangan, HUNAFA: Jurnal Studia Islamika, 2013, 10.2, h. 241 demi menjaga keutuhan dan kebahagiaan rumah tangga. Bila dicermati, dalam kajian fikih, poligami bukanlah perkara wajib, bahkan fikih tidak menghendaki seseorang untuk berpoligami. ${ }^{13}$ Karena itu, persyaratan poligami begitu ketat diberikan oleh Alqur'an, yakni harus adil. Sedangkan konsep adil itu sendiri sangatlah relatif. Karena itu, praktik poligami harus diiringi dengan syarat-sayarat yang memiliki ruh berdasarkan maksud syariatnya. Misalnya, sebab umum yang menjadi keringanan berpoligami ialah minimnya jumlah pria disebabkan oleh peperangan, bencana, ataupun fenomena angka kelahiran yang minim. Dalam kondisi seperti, menjaga poligami bisa menjadi pilihan untuk menjaga anak-anak yatim maupun kaum perempuan. Sedangkan bila dari penyebab khusus, misalnya karena kondisi biologis seksual yang tidak seimbang, tidak memiliki keturunan, dan lainnya. Namun, semua itu perlu pertimbangan berdasarkan mashlahahnya, bukan serta merta mengikuti hawa nafsu belaka.

Pengadilan agama, sebagai lembaga yang berhak memberikan keputusan, apakah seseorang diperbolehkan atau tidak untuk berpoligami, patut memeriksa secara benar perihal izin dari istrinya. Sebagaimana disebutkan pada pasal 5 UU Perkawinan dan pasal 58 PP Nomor 1 Tahun 1975, bahwa izin itu bisa tertulis dan bisa juga berupa izin lisan. Dalam hal ini, dua pola tersebut telah diterapkan secara bersamaan oleh Pengadilan Agama, yakni izin tertulis yang kemudian dipriksa kembali oleh hakim dengan menghadirkan istri yang membuat pernyataan pada persidangan. Dari sanalah, akan terlihat korelasi antara izin tertulis dengan pengakuan secara lisan untuk dijadikan acuan dalam pengambilan keputusan. Maka, dalam perspektif mashlahah mursalah, pemeriksaan izin istri di depan persiangan merupakan

${ }^{13}$ Ibid, h. 249-250 
kebutuhan hajiyah (kebutuhan pokok) untuk menunjang kebutuhan mutlak.

Dari paparan di atas, tunjauan dari perspektif mashlahah mursalah terhadap aturan perundang-undangan tentang poligami di Indonesia terlihat berusaha menghargai istri sebagai pasangan hidup suami. Hal ini terlihat dari ketentuan dan mekanisme yang cukup ketat, termasuk adanya persetujuan dari istri. Untuk itu ini perundang-undangan Indonesia memberikan kepercayaan sepenuhnya kepada hakim di Pengadilan Agama. Jadi, perundangundangan Indonesia mengenai poligami, meskipun Alquran jelas mengizinkan seorang laki-laki menikah lebih dari satu, namun perundangundangan Indonesia melarangnya. Pelarangan semacam itu karena kerugiannya (mafsadab) lebih besar daripada keuntungannya (mashlahab). ${ }^{14}$ Sedangkan persetujuan isteri bagi suami yang berpoligami sangat diperlukan demi untuk menjaga keharmonisan rumah tangga. Menjaga keharmonisan rumah tangga adalah bagian dari maqhasid al-syariah, karena tujuan syara' dalam menetapkan suatu hukum untuk makhluk itu ada lima, yaitu: memelihara agama, memelihara jiwa, memelihara akal pikiran, memelihara keturunan, dan memelihara harta.

\section{A. Kesimpulan}

Dari uraian di atas, izin istri bagi seorang suami yang hendak berpoligami merupakan persyaratan untuk mendapatkan ketetapan oleh pengadilan. Namun, izin itu semestinya tidak hanya berupa izin tertulisa saja melainkan harus juga dibuktikan dengan kesaksian langsung di depan persidangan. Dari perspektif mashlahah mursalah, izin dari istri termasuk bagian yang dharuriyah (mutlak) bagi hakim dalam mempertimbangkan permohonan

${ }^{14}$ Muhibbuthabry, Poligami dan Sanksinya Menurut Perundang-undangan Negara-negara Modern, AHKAM: Jurnal Ilmu Syariah, 2016, 16.1. h. 17 poligami. Sedangkan memeriksa kesaksian istri di pengadilan merupakan bagian burriyah (kebutuhan pokok) untuk menunjang kebutuhan yang dharuriyah (mutlak). Dengan demikian, dalam pemeriksaan perkara permohonan poligami, hakim Pengadilan Agama tidak hanya mengandalkan izin tertulis saja melainkan juga dengan pemeriksaan langsung terhadap istri yang memberikan. 


\section{Daftar Pustaka}

Irawan, Candra Sabtia, Perkawinan dalam Islam: Monogami atau Poligami?, Yogyakarta: An Naba', 2007.

Jafar, Wahyu Abdul, Kerangka Istinbath Maslahah Mursalab Sebagai Alternatif Problem Solving Dalam Hukum Islam, ISTINBATH: Jurnal Hukum, 2016, 13.1: 89-108. http://ejournal.metrouniv.ac.id/index.php/istinbath/article/view/544

Jamal, Ridwan, Hukum Poligami Menurut Undang-Undang Perkawinan Dan Fikhi, Jurnal Ilmiah AlSyir'ah2.1 (2016). http://dx.doi.org/10.30984/as.v2i1.217

Makrum, Poligami dalam Perspektif Al-Qur'an, MAGHZA: Jurnal Ilmu Al-Qur'an dan Tafsir, 2016, 1.2: 35-50. https://doi.org/10.24090/maghza.v1i2.739

Muhibbuthabry, Poligami dan Sanksinya Menurut Perundang-undangan Negara-negara Modern, AHKAM: Jurnal Ilmu Syariah, 2016, 16.1. http://dx.doi.org/10.15408/ajis.v16i1.2891

Nasution, Khoirudin, Riba \& Poligami: Sebuah Studi atas Pemikiran Mubammad Abduh, Yogyakarta: Pustaka Pelajar, 1996.

Peraturan Pemerintah Nomor 10 Tahun 1983 tentang Izin Perkawinan dan Perceraian bagi Pegawai Negeri Sipil (PNS) Republik Indonesia

Peraturan Pemerintah nomor 45 tahun 1990 tentang Perubahan atas Peraturan Nomor 10 tahun 1983 tentang Izin Perkawinan dan Perceraian bagi Pegaiwai Negeri Sipil (PNS) Repbulik Indonesia

Rahmawati, Sri W. Pengambilan Keputusan Seorang Istri Dalam Pernikahan Poligami, Jurnal Psikologi Ulayat: Indonesian Journal of Indigenous Psychology, 2013, 1.2: 163-176. http://dx.doi.org/10.24854/jpu22013-18

Riyandi, S. Syarat Adanya Persetujuan Isteri Untuk Berpoligami (Analisis Ushul Fikih Syafi İyah Terbadap Undang-Undang Perkawinan Nomor 1 Tabun 1974). Jurnal Ilmiah Islam Futura, 2015, 15.1: 111-142. http://dx.doi.org/10.22373/jiif.v15i1.561

Rusfi, Muhammad, Validitas Maslahah Mursalah Sebagai Sumber Hukum, Al-'Adalah, 2017, 12.1: 6374. http://ejournal.radenintan.ac.id/index.php/adalah/article/view/175/415

Shahrur, Muhammad, "Nahw Usul Jadidah Li al-Fiqh al-Islami” terj., Sahiron Syamsuddin dan Burhanuddin, Metodologi Fiqh Islam Kontemporer, Yogyakarta: eLSAQ Press, 2004.

Syarifuddin, Amir, Hukum Perkawinan Islam di Indonesia: Antara Fiqh Munakahat dan Undang-Undang Perkawinan, Jakarta: Kencana, 2007.

UU No. 1 Tahun 1974 tentang Perkawinan

Wartini, Atik, Poligami: Dari Fiqh Hingga Perundang-Undangan, HUNAFA: Jurnal Studia Islamika, 2013, 10.2: 237-268. https://doi.org/10.24239/jsi.v10i2.29.237-268

Zainuddin dan Afwan Zainuddin, Kepastian Hukum Perkawinan Siri dan Permasalahannya Ditinjau dari Undang-Undang Nomor 1 Tahun 1974, Yogyakarta: Deepublihs, 2017. 